\title{
Micro-pollutants in urban residential roof runoff: Environmental and health implications.
}

\author{
Adedeji, Oludare $\mathrm{H}$ and Olayinka, Olufunmilayo O. \\ Department of Environmental Management and Toxicology Federal University of Agriculture, PMB 2240, \\ Abeokuta, Nigeria
}

\begin{abstract}
This study assessed concentration of micro-pollutants (heavy metals- $\mathrm{Cd}, \mathrm{Cu}, \mathrm{Fe}, \mathrm{Mn}, \mathrm{Pb}$, and $\mathrm{Zn}$; organic compound - PAHs, pathogenic microorganisms) in ambient and harvested rainwater under urban residential rooftops. Samples were analysed using standard analytical procedures. Rainwater harvested from the rooftops were alkaline (8.5-9.6) compared to $\mathrm{pH}$ of 5.94 for the ambient rainwater. Conductivity ranged from $95.2-150.4 \mu \mathrm{S} / \mathrm{cm}$ due to the dissolution of deposited aerosols and leaching of roofing materials. Turbidity, $\mathrm{Cu}$, and microbial counts (HPC, E. coli, TC and FC) exceeded the allowable limits for drinking water with inputs from the rooftops. Concentration of $\mathrm{Cu}$ and $\mathrm{Pb}$ in harvested rainwater was higher than the WHO standards. Relative abundance of metals is as follows: $\mathrm{Fe}>\mathrm{Zn}>\mathrm{Cu}>\mathrm{Mn}>\mathrm{Pb}>\mathrm{Cd}$. Water quality from asbestos was the worst among the rooftops examined. Total PAHs was low ranging from 0.04 found in ambient rainwater to 0.18 in rusted galvanized iron sheet. All samples contain high amount of microbiological contaminants with the asbestos roofing sheet having TC and E. coli of 14000 and $12000 \mathrm{cfu} / \mathrm{mL}$ respectively. These can result in illnesses such as diarrhoea, urinary tract infections, respiratory illness and pneumonia. The study had shown that rooftops contributed significantly to contamination of harvested rainwater due to composition of roofing materials and age of the roof.
\end{abstract}

Keywords: Ambient rainwater, atmospheric deposition, E. coli, harvested rainwater, micro-pollutants, PAHs, roofing sheets

\section{INTRODUCTION}

Environmental health problems have become a major source of concern worldwide, especially on the issue of the quality of environmental factors such as water. According to the World Health Organisation, just about $60 \%$ of the population in sub-Saharan Africa uses improved sources of drinking water ${ }^{[1]}$. Many rural and urban households in Africa rely on rainwater harvested from roof catchments to provide water for use ${ }^{[2-3]}$. Rainwater harvesting (RWH) is the collection of rainwater from a surface known as catchment (roofs and ground surfaces); and its storage in physical structures or within the soil profile ${ }^{[4-6]}$. Although rainwater harvesting has been identified as among the important interventions necessary towards meeting the MDGs in Africa $^{[5]}$, roof runoff is known as a potential source of nonpoint pollution ${ }^{[7]}$. Urban residential roofs are made up of different materials containing compounds that can leach into rainwater together with atmospherically deposited materials that easily dissolve into the runoff ${ }^{[6,8]}$.

Roofing materials are generally responsible for the presence of toxic pollutants such as copper, zinc, cadmium and lead that leach from the roof materials into the runoff $\left[^{9-11]}\right.$. The leached materials contribute relatively high pollutant loads to the runoff and hence significantly contaminate harvested rainwater ${ }^{[4,6,12-13]}$. Roof materials, age, atmospheric depositions, and meteorological conditions affect the quality of harvested rainwater from urban rooftop ${ }^{[14]}$. Contaminants in roof runoff include micro-pollutants, pathogenic microorganisms, and nutrients ${ }^{[15]}$. Micro-pollutants are trace organic contaminants or metals found in waters at very low concentrations (billionths to millionths of a gram per litre ${ }^{[16]}$ ) and can be divided into two broad categories: metals $(\mathrm{Cd}, \mathrm{Cr}, \mathrm{Cu}, \mathrm{Mn}, \mathrm{Ni}, \mathrm{Pb}$, and $\mathrm{Zn})$ and organic compounds such as polycyclic aromatic hydrocarbons PAHs, PCBs and pesticides ${ }^{[4]}$. Heavy metals, PAHs, and pathogenic microorganisms are of particular concern in urban atmospheric deposition and rooftop runoff ${ }^{[13]}$. Triebskorn et al. ${ }^{[17]}$ asserted the need to minimize the risk for man and the environment resulting from micro-pollutant and pathogen discharges. Few studies have focused attention on the contribution of atmospheric deposition and roofing materials to the quality of harvested rainwater. There is the need for accurate evaluation of contaminant flows from roofs considering the predominance of metallic roofing materials in majority of the houses in our towns and cities ${ }^{[18]}$. This research work aims to establish the combined effect of typical urban roofing material and roof conditions on the quality of harvested roof runoff. It seeks to understand the characteristics of pollutant build-up and wash-off from roof surfaces and thus to contribute to the knowledge needed for improving harvested rainwater quality. 
Micro-pollutants in urban residential roof runoff: Environmental and health implications.

\section{MATERIAL AND METHODS}

\subsection{Study Area}

Ijebu-ode is situated in Ogun State, southwest Nigeria. It is approximately located between latitudes $6^{\circ} 42^{\prime} \mathrm{N}$ and $6^{\circ} 54^{\prime} \mathrm{N}$ and longitude $3{ }^{\circ} 55^{\prime} \mathrm{E}$ and $4^{\circ} 61 \mathrm{E}$ (Figure 1). The climate fall into two distinct seasons i.e. the harmattan season (November to March) and the raining season (April to October) interrupted by short August break. The rains reach its peak in the months of June and September. The mean annual rainfall is about $1590 \mathrm{~mm}$; with an average annual temperature is $27.5^{\circ} \mathrm{C}$. Ijebu-ode is the second largest urban area in the state after Abeokuta, the capital with a population of about $153,032^{[19]}$ and population density of 481 persons per hectare..

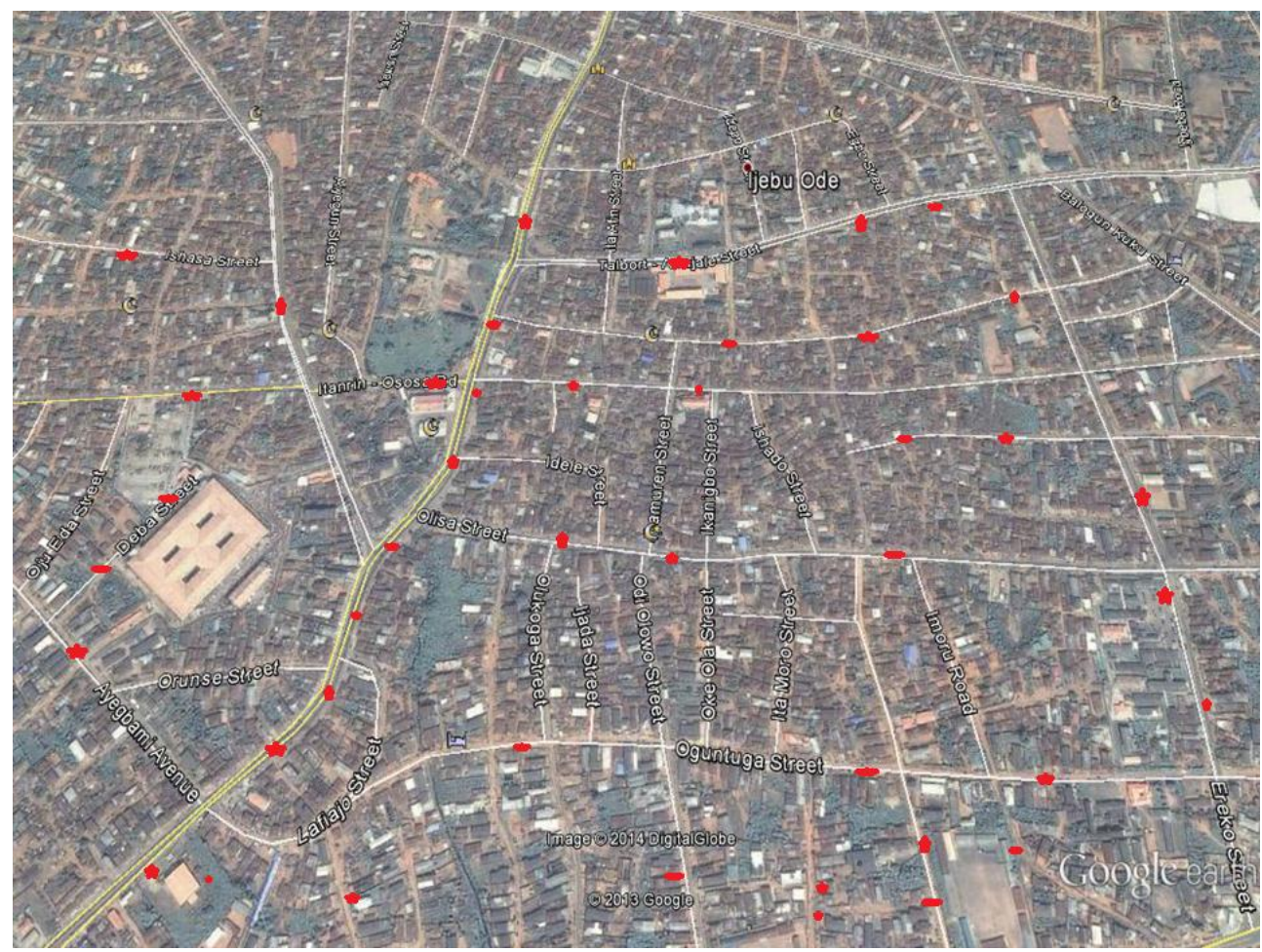

Figure 1: Map of Ijebu-Ode showing sample locations

Various types of buildings cater for the demands of the growing population. Characteristics of roofing materials used for the buildings are shown in Table 1

Table 1: Characteristics of the urban roofs (catchments) and traffic flow along highways in Ijebu-ode

\begin{tabular}{|c|c|c|c|}
\hline$\overline{\text { Roof Area }\left(\mathrm{m}^{2}\right)}$ & Cover Material & Slope & Traffic flow \\
\hline Roof 1264 & Recent galvanized iron sheet & 0.21 & 560 \\
\hline Roof $2 \quad 245$ & Rusted galvanized iron sheet & 0.24 & 254 \\
\hline Roof $3 \quad 540$ & Aluminium longspan sheet & 0.34 & 1600 \\
\hline Roof $4 \quad 229$ & Asbestos & 0.21 & 600 \\
\hline
\end{tabular}

\subsection{Sampling and Instrumentation}

The methodology adopted for this work was laboratory analysis of residential roof runoff and bulk open precipitation (ambient rainwater). Samples were collected weekly between June to October for two years in 2010 and 2011 during the raining season from different parts of Ijebu-ode. The houses chosen were all sufficiently close to the major highways where vehicular emission and road dust could easily settle on the roof surfaces ${ }^{[20]}$. The buildings were of different types including bungalows, single story flats and duplexes all of which were oriented at a right angle to the highway on relatively flat grounds. The rooftops of the buildings in the study area were of varying dimension; however, for this study rooftops selected had an average dimension of $11.5 \times 22.6$ metres and average surface area of $259.9 \mathrm{~m}^{2}$. The rooftops had an average slope of 0.24 , which allowed rainwater harvesting from at least two sides of the buildings (Table 1). This study highlighted the condition to collect the first flush that contains the initial and highly polluted portion of roof runoff ${ }^{[13]}$. Fifteen (15) rainfall events were collected each year during the study period. Bulk atmospheric deposition (direct rainfall) was collected using two types of collectors: a stainless steel funnel for samples to be analyzed for organic pollutant (PAHs), while the Owen gauges were used to collect samples aimed at heavy metal analysis 
${ }^{21]}$. The collector areas were $0.034 \mathrm{~m}^{2}$ and $0.066 \mathrm{~m}^{2}$ respectively. Roof runoff samples were collected from four different rooftop types, which were common in the study area i.e. recent galvanized iron sheet, rusted galvanized iron sheet, aluminium long span sheet, and asbestos sheet. The samples for each roof was collected in 120-L acid leached polythene containers for the determination of heavy metal concentrations of selected metals through PVC gutters established at their base.

\subsection{Laboratory Analysis}

Sample $\mathrm{pH}$, temperature, conductivity, total suspended solids (TSS), total dissolved solids (TDS), total organic carbon (TOC) and electrical conductivity (EC) were determined by standard procedures ${ }^{[22]}$. Turbidity was determined using the Hach turbidity meter model $2100 \mathrm{~A}^{[23]}$. Samples were also analysed for the inorganic ions $\mathrm{Cl}^{-}, \mathrm{NO}_{3}^{-}, \mathrm{NO}_{2}^{-}, \mathrm{SO}_{4}{ }^{2-}, \mathrm{Ca}^{2+}$ and $\mathrm{Na}^{+}$, according to standard procedures ${ }^{[22]}$. Concentrations of heavy metals $(\mathrm{Cd}, \mathrm{Cu}, \mathrm{Fe}, \mathrm{Mn}, \mathrm{Pb}$ and $\mathrm{Zn})$ in ambient rainwater and roof runoff were determined using a computerized Buck Scientific model 210 VGP atomic absorption spectrophotometer (AAS). Standard solutions of the respective metals were used for instrument calibration and all chemicals were of analytical grade. Samples for heavy metal determination were first subjected to digestion using the wet digestion method. $5 \mathrm{ml}$ of the samples was weighed into digestion tubes. One tablet of selenium catalyst was placed inside each tube and $10 \mathrm{ml}$ of concentrated hydrochloric acid and 10mls of concentrated nitric acid at ratio 1:1 was added. The tubes were then placed inside a digestion block and slowly digested. The digest was washed into $100 \mathrm{~mL}$ volumetric flask and made up with distilled water. The samples were centrifuged at 3000rpm for 30 minutes to get the supernatant from the sample. The washed samples were then read on an Atomic Absorption spectrophotometer (AAS) using their respective lamp and wavelengths. Fifteen (15) out of the 16 polycyclic aromatic hydrocarbons (PAHs) recommended by the Environmental Protection Agency (EPA): Naphthalene (NP), Acenaphthene (ACE), Fluorene (FLU), phenanthrene (PHE), anthracene (ANT), fluoranthene (FTH), Pyrene (PYR), Benzo(a)anthracene (BaA), Chrysene (CHR), Benzo(b)fluoranthene (BbF), Benzo(k)fluoranthene (BkF), Benzo(a)pyrene (BaP), Indeno(1,2,3-c,d)pyrene (IcdP), Dibenzo(a,h)antracene (Db(ah)An), Benzo(g,h,i)perylene (BghiP) were analyzed. The quantification limits for PAHs is $2.0 \mathrm{ng} \mathrm{L}-1$ with exception of NP, FLU, PHE and ANT $\left(10 \mathrm{ng} \mathrm{L}^{-1}\right) .10 \mathrm{~g}$ of the samples was weighed in to beaker and 50ml of Hexane was added. It was shaken on a mechanical shaker and the solution was separated using a separating funnel. It was then filtered using a No.1 Whatman filter paper. The solvent was evaporated at room temperature by placing it in a fume cupboard. The filtrates were read on a spectronic 21D at $410 \mathrm{nM}$ wavelength. The standard was prepared from a standard curve. The standard was prepared from the petroleum Hydrocarbon (diesel, kerosene, petrol) at 2, 4, 6,8,10 PPM of the hydrocarbon.

\subsection{Microbiological contaminants}

For this study, all collected samples were examined for heterotrophic plate count (HPC), total coliform (TC), faecal coliform, (FC) and E. coli counts, using the Millipore filtration system. Sample aliquots were filtered and plated onto HPC; Coliform counts provide a measure of possible faecal contamination, and HPC a measure of overall bacterial load ${ }^{[4,12]}$.

\subsection{Roof runoff quality and ambient rainwater}

\section{RESULTS AND DISCUSSIONS}

The study was conducted in 2010 and 2011 during the raining season with average rainfall duration of at least more than two hours each day representing over $70 \%$ of the rain events. The total precipitation was approximately 345 to $402 \mathrm{~mm}$. The pHs of the harvested rainwater from different rooftops were generally higher than that of ambient rainwater ranging from 8.50- 10.53. The $\mathrm{pH}$ of 5.94 recorded for the ambient rainwater is within the acceptable limit for drinking water. Rainwater from all the investigated rooftops tends towards alkalinity (Table 2). The $\mathrm{pH}$ values obtained in this study agreed with the result of Yaziz et al., ${ }^{[25]}$. Furthermore, Simmons et al. ${ }^{[26]}$ in a study of Auckland, New Zealand reported pH values of 5.2 to 11.4 for harvested rainwater. The alkalinity of the harvested rainwater could be caused by the presence of alkaline soil particles from deposition and wind erosion, which dissolved in the rainwater ${ }^{[27]}$. The samples collected under the rusted galvanized iron sheet exhibited the highest conductivity followed by asbestos, aluminium long span sheet; recent galvanized iron sheet and ambient rainwater respectively (Table 3). Conductivity values in the ambient rainwater ranged from $23-50 \mu \mathrm{S} / \mathrm{cm}$, which falls within Mendez et al. ${ }^{[11]}$ that range from 18 to 61 $\mu \mathrm{S} / \mathrm{cm}$. Higher conductivity was recorded for harvested rainwater from the different rooftops ranging from 95.2 $-150.4 \mu \mathrm{S} / \mathrm{cm}$. 
Micro-pollutants in urban residential roof runoff: Environmental and health implications.

Table 1: Descriptive statistics of physico-chemical properties of harvested rainwater

\begin{tabular}{|c|c|c|c|c|c|c|c|}
\hline & \multirow[b]{2}{*}{ pH } & \multicolumn{4}{|c|}{ Bulk open precipitation (Ambient rain) } & \multirow[b]{2}{*}{ Turbidity } & \multirow[b]{2}{*}{ TOC } \\
\hline & & Conductivity & Acidity & TSS & TDS & & \\
\hline Mean & 5.87 & 39.33 & 7.53 & 14.17 & 1.23 & 10.33 & 10.40 \\
\hline Median & 5.94 & 45.00 & 7.50 & 15.20 & 1.20 & 10.00 & 10.50 \\
\hline Standard Deviation & 0.18 & 14.56 & 0.15 & 3.47 & 0.06 & 11.53 & 0.36 \\
\hline Range & 0.34 & 27.00 & 0.30 & 6.70 & 0.10 & 3.00 & 0.70 \\
\hline Minimum & 5.66 & 23.00 & 7.40 & 10.30 & 1.20 & 9.00 & 10.00 \\
\hline Maximum & 6.00 & 50.00 & 7070 & 17.00 & 1.30 & 12.00 & 10.70 \\
\hline \multicolumn{8}{|c|}{ Recent galvanized iron sheet } \\
\hline Mean & 9.89 & 94.63 & 13.57 & 88.50 & 4.63 & 70.00 & 36.00 \\
\hline Median & 9.90 & 95.20 & 13.50 & 88.50 & 4.60 & 70.00 & 36.00 \\
\hline Standard Deviation & 0.11 & 5.67 & 0.60 & 1.50 & 0.55 & 10.00 & 6.56 \\
\hline Range & 0.82 & 11.30 & 1.20 & 3.00 & 1.10 & 20.00 & 13.00 \\
\hline Minimum & 9.38 & 88.70 & 13.00 & 87.00 & 4.10 & 60.00 & 30.00 \\
\hline Maximum & 10.20 & 100.00 & 14.20 & 90.00 & 5.20 & 80.00 & 43.00 \\
\hline \multicolumn{8}{|c|}{ Rusted galvanized iron sheet } \\
\hline Mean & 10.53 & 151.80 & 19.13 & 146.00 & 12.70 & 97.00 & 66.33 \\
\hline Median & 10.60 & 150.40 & 19.00 & 146.00 & 12.70 & 97.00 & 67.00 \\
\hline Standard Deviation & 0.25 & 7.60 & 3.80 & 1.00 & 0.10 & 1.00 & 20.01 \\
\hline Range & 0.50 & 15.00 & 7.60 & 2.00 & 0.20 & 2.00 & 40.00 \\
\hline Minimum & 10.30 & 145.00 & 15.40 & 145.00 & 12.60 & 96.00 & 46.00 \\
\hline Maximum & 10.80 & 160.00 & 23.00 & 147.00 & 12.80 & 98.00 & 86.00 \\
\hline \multicolumn{8}{|c|}{ Aluminium longspan sheet } \\
\hline Mean & 9.85 & 105.20 & 12.17 & 43.37 & 11.43 & 73.33 & 44.33 \\
\hline Median & 9.80 & 105.60 & 12.00 & 43.00 & 11.50 & 73.00 & 42.00 \\
\hline Standard Deviation & 0.13 & 5.01 & 0.38 & 1.48 & 0.60 & 6.51 & 11.68 \\
\hline Range & 0.25 & 10.00 & 0.70 & 2.90 & 1.20 & 13.00 & 23.00 \\
\hline Minimum & 9.75 & 100.00 & 11.90 & 42.10 & 10.80 & 67.00 & 34.00 \\
\hline Maximum & 10.00 & 110.00 & 12.60 & 45.00 & 12.00 & 80.00 & 57.00 \\
\hline \multicolumn{8}{|c|}{ Asbestos } \\
\hline Mean & 8.50 & 135.93 & 18.63 & 207.27 & 14.23 & 92.00 & 65.00 \\
\hline Median & 8.60 & 135.80 & 18.50 & 207.80 & 14.70 & 92.00 & 64.00 \\
\hline Standard Deviation & 0.10 & 6.00 & 0.32 & 2.05 & 1.08 & 2.00 & 14.53 \\
\hline Range & 1.20 & 12.00 & 0.60 & 4.00 & 2.00 & 4.00 & 29.00 \\
\hline Minimum & 7.50 & 130.00 & 18.40 & 205.00 & 13.00 & 90.00 & 51.00 \\
\hline Maximum & 8.70 & 142.00 & 19.00 & 209.00 & 15.00 & 94.00 & 80.00 \\
\hline
\end{tabular}

The conductivity of roof runoff was considerably higher than ambient rainwater probably due to the initial dissolution of deposited aerosols and weathering products, followed by continuous leaching of roofing material. The highest value of acidity was from the asbestos roofing sheets, followed by rusted galvanized iron sheet, aluminium long span sheet, recent galvanized iron sheet, and ambient rainwater respectively. The TDS concentrations were generally low in this study (Table 3). TDS level ranges from $1.23 \mathrm{mgL}^{-1}$ in the ambient rainwater to $14.23 \mathrm{mgL}^{-1}$ in rainwater harvested under asbestos catchments. These are below allowable limit of $500 \mathrm{mgL}^{-1}$ for drinking water ${ }^{[28]}$. Although TDS concentration is a secondary standard for drinking water, high TDS affect the aesthetic quality of water. High TDS content also signifies the presence of ions such as nitrate, aluminium, copper, and lead that are above the standards for drinking water. Furthermore, it should be noted that water with a very low TDS concentration might be corrosive causing toxic metals such as copper and lead to leach from the roofing materials, which may pose a health risk ${ }^{[29]}$.

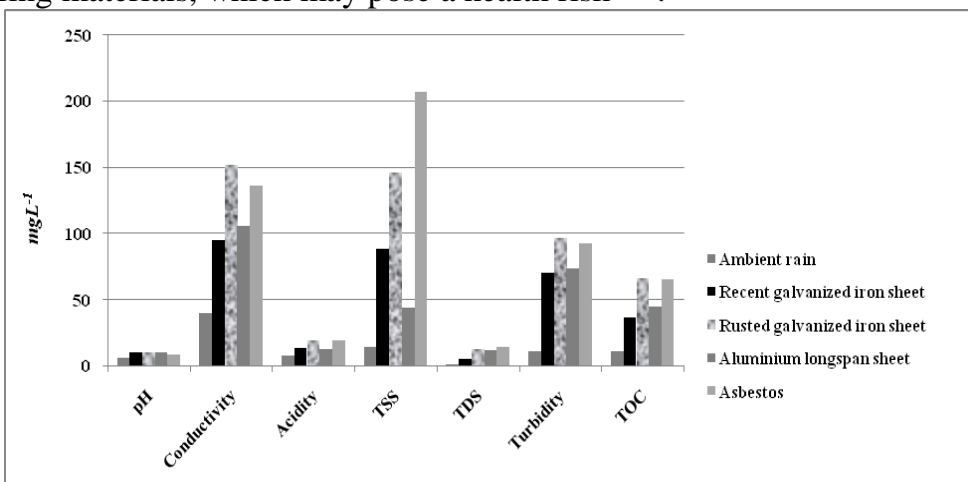

Figure 2. Mean pH, TSS, TDS, acidity, conductivity, turbidity and TOC in harvested rainwater

The acidic nature of ambient rainwater may cause the chemical compounds (such as cadmium, copper, lead, zinc, and chromium) from roofing materials to leach into the harvested rainwater ${ }^{[4,6,26]}$. Total suspended solids (TSS) in the harvested rainwater under the different rooftops show a high variability. TSS varies from 
$15.2 \mathrm{mg} \mathrm{L}^{-1}$ in ambient rainwater to $207.8 \mathrm{mg} \mathrm{L}^{-1}$ in asbestos roof runoff. Roof runoff especially the first flush may contain elevated concentration of suspended solids ${ }^{[30-31]}$ compared to rainwater whose suspended solids concentration and turbidity is expected to be low. Higher concentrations of suspended solids can serve as carriers of toxics, which readily cling to suspended particles. TSS had the highest concentration in asbestos roof followed by rusted galvanized iron sheet, recent galvanized iron sheet; aluminium longspan sheet and bulk open precipitation in that order respectively. A high concentration of total solids will make drinking water unpalatable and might have an adverse effect on people who are not used to drinking such water. Turbidity readings ranged from mean value of 10 nephelometric turbidity units (NTU) in the ambient rainwater to 96 NTU in harvested rain under the rusted galvanized iron sheet. The turbidity values obtained were similar to 3 to 105 NTU reported by Mendez et al. ${ }^{[11]}$ and 4 to 94 NTU reported in Yaziz et al. ${ }^{[11]}$. Mendez et al. ${ }^{[11]}$ observed that roofs with smoother surfaces such as metals and tiles might have higher turbidity values as compared to other roofing materials. Generally, turbidity values reported in this study were above the one (1) NTU maximum recommended for potable use of harvested rainwater (USEPA, 2009). TOC concentrations of the harvested rainwater during the study period ranged from a mean $\pm \mathrm{SD}$ of $10.34 \pm 0.36 \mathrm{mgL}^{-1}$ in the ambient rainwater to $66.33 \pm 20.01$ in the water collected under the recent galvanized iron sheet (Table 3). The PPMCC analysis shows that there are strong positive correlations among water quality parameters such as conductivity, TDS, TSS and turbidity (Table 4).

Correlations between conductivity and TDS were 0.91, while correlation between TSS and conductivity was 0.83 at a 0.05 significance level showing significant relationships among these parameters.

Table 3. Correlations (PPMCC) among water quality parameters in harvested rainwater

\begin{tabular}{|c|c|c|c|c|c|c|c|}
\hline & $\mathrm{pH}$ & Conductivity & Acidity & TSS & TDS & Turbidity & TOC \\
\hline pH & 1.00 & & & & & & \\
\hline Conductivity & 0.85 & 1.00 & & & & & \\
\hline Acidity & 0.76 & 0.97 & 1.00 & & & & \\
\hline TSS & 0.47 & 0.83 & 0.93 & 1.00 & & & \\
\hline TDS & 0.64 & 0.91 & 0.84 & 0.75 & 1.00 & & \\
\hline Turbidity & 0.85 & 0.98 & 0.93 & 0.79 & 0.88 & 1.00 & \\
\hline TOC & 0.77 & 0.99 & 0.97 & 0.87 & 0.94 & 0.96 & 1.00 \\
\hline
\end{tabular}

\subsection{Macro and Micro Nutrients}

Asbestos roofing sheet has the highest concentration of all the macro and micronutrients monitored in this study, except for $\mathrm{NO}_{2}^{-}$in which the rusted galvanized iron sheet has slightly higher concentration (Figure 3). Nitrate $\left(\mathrm{NO}_{3}{ }^{-}\right)$is the most chemically stable form of nitrogen unlike nitrite $\left(\mathrm{NO}_{2}{ }^{-}\right)$which is a relatively unstable intermediate in the conversion between nitrate and ammonia. Nitrate concentration in ambient rainwater ranged from $0.002 \mathrm{mgL}^{-1}$ to $0.08 \mathrm{mgL}^{-1}$ in the harvested rainwater under the rusted galvanized iron sheet (Figure 3).

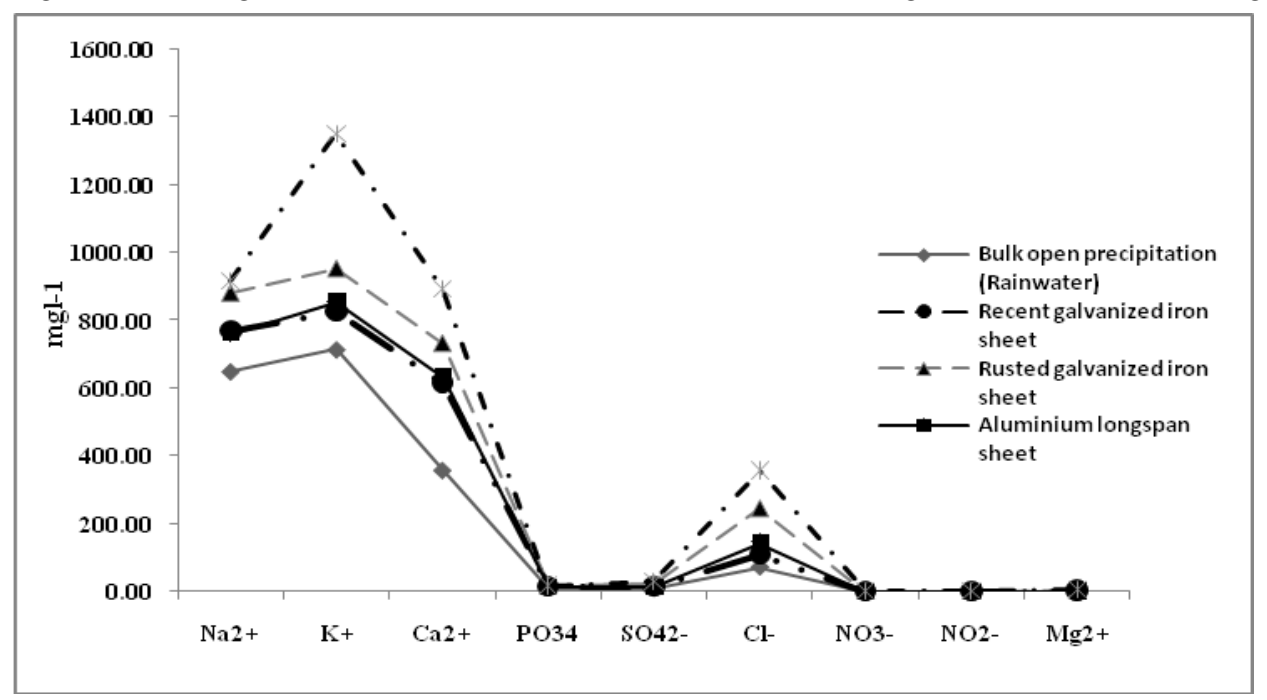

Figure 3. Concentration of ionic compounds in the ambient and harvested rainwater

These values were however below the USEPA drinking water maximum contaminant limit (MCL) of $10 \mathrm{mgL}^{-1}$ nitrate ${ }^{[15]}$. On the other hand, nitrite $\left(\mathrm{NO}_{2}{ }^{-}\right)$concentrations in rainwater harvested ranged from 0.00 to 0.02 $\mathrm{mgL}^{-1}$, which are also below the USEPA drinking water MCL for nitrite, which is $1 \mathrm{mgL}^{-1}$. $\mathrm{NO}_{2}^{-}$is a rough indicator of proximity to a pollution source and usually occurs at very low levels in well-oxygenated waters ${ }^{[24]}$. Potassium, Sodium and Calcium were found in higher concentration to other elements probably due to the fact that they are easily leached and mostly of local origin. These elements are often contained in aerosols and particulate matter deposited during wet and dry atmospheric deposition ${ }^{[6]}$. From a source perspective, $\mathrm{Na}^{+}$and 
$\mathrm{Cl}^{-}$are principle components of sea salt. Chloride concentration can be attributing to marine source especially the Atlantic Ocean, which is about $80 \mathrm{~km}$ from the study area. $\mathrm{SO}_{4}{ }^{2-}$ and $\mathrm{NO}_{3}{ }^{-}$together represent the major ionic derivatives of industrial and traffic emissions.

Table 4. Correlations (PPMCC) among ions in the harvested rainwater

\begin{tabular}{|c|c|c|c|c|c|c|c|c|c|}
\hline & $\mathrm{Na}^{2+}$ & $\mathbf{K}^{+}$ & $\mathrm{Ca}^{2+}$ & $\mathrm{PO}_{3}{ }^{4}$ & $\mathrm{SO}_{4}{ }^{2-}$ & $\mathrm{Cl}^{-}$ & $\mathrm{NO}_{3}{ }^{-}$ & $\mathrm{NO}_{2}{ }^{-}$ & $\mathrm{Mg}^{2+}$ \\
\hline $\mathrm{Na}^{2+}$ & 1 & & & & & & & & \\
\hline $\mathbf{K}^{+}$ & 0.86 & 1.00 & & & & & & & \\
\hline $\mathrm{Ca}^{2+}$ & 0.97 & 0.90 & 1.00 & & & & & & \\
\hline $\mathrm{PO}_{3}{ }^{4}$ & 0.87 & 0.57 & 0.77 & 1.00 & & & & & \\
\hline $\mathrm{SO}_{4}{ }^{2-}$ & 0.97 & 0.95 & 0.95 & 0.78 & 1.00 & & & & \\
\hline $\mathrm{Cl}^{-}$ & 0.93 & 0.96 & 0.92 & 0.76 & 0.98 & 1.00 & & & \\
\hline $\mathrm{NO}_{3}{ }^{-}$ & 0.68 & 0.24 & 0.52 & 0.83 & 0.53 & 0.42 & 1.00 & & \\
\hline $\mathrm{NO}_{2}^{-}$ & 0.88 & 0.60 & 0.89 & 0.83 & 0.75 & 0.69 & 0.70 & 1.00 & \\
\hline $\mathrm{Mg}^{2+}$ & 0.93 & 0.82 & 0.97 & 0.80 & 0.88 & 0.87 & 0.48 & 0.92 & 1.00 \\
\hline
\end{tabular}

The PPMCC analysis shows that there is a strong positive correlation of 0.873 between TDS and conductivity at a 0.01 significance level(Table 4), therefore, TDS affects conductivity.

\subsection{Heavy metals}

$\mathrm{Fe}, \mathrm{Cu}$ and $\mathrm{Zn}$ were the main metals leaching from roofs. Concentrations of these metals show high variability between the four different roof catchments. There are significant differences $(p<0.05)$ from ambient rainwater compared to the different rooftop (Figure 4). Rainwater collected under asbestos roofing sheets has heavy metals ranging from $3.37 \mathrm{mgL}^{-1}$ for $\mathrm{Cu}$ to $6.33 \mathrm{mgL}^{-1}$ for $\mathrm{Zn}$. Mean concentration of Fe in the rainwater collected under asbestos roofing sheet was $6.33 \mathrm{mgL}^{-1}$ with a standard deviation of 0.25 .

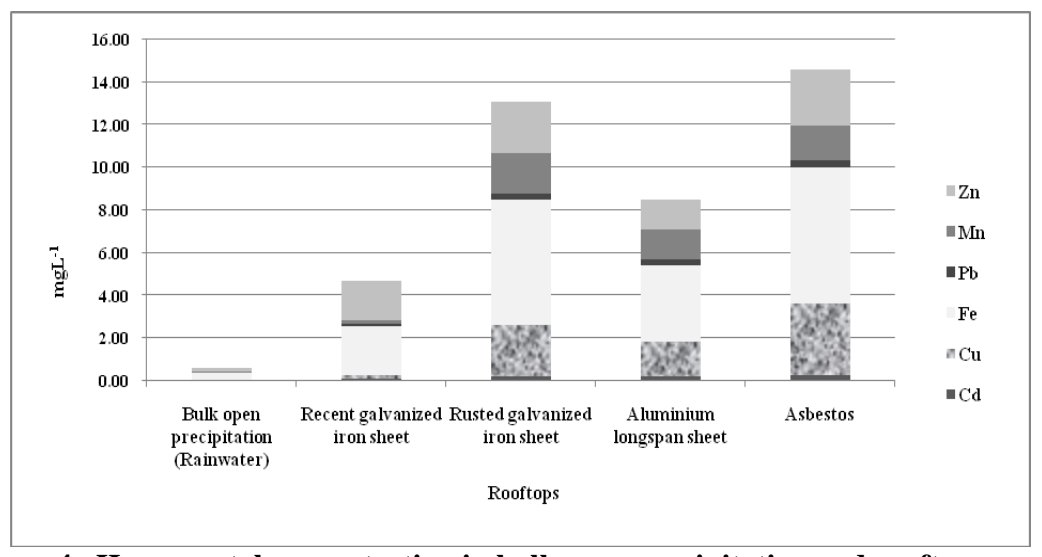

Figure 4. Heavy metal concentration in bulk open precipitation and rooftop runoffs

This value is higher than the mean of $0.36 \mathrm{mg} / \mathrm{L}$ recorded for Fe concentration in ambient rainwater. Metal concentrations in harvested water under rusted galvanized iron roofing sheet catchment ranged from 0.24 $\mathrm{mg} / \mathrm{L}$ for $\mathrm{Cd}$ to $5.86 \mathrm{mgL}^{-1}$ for $\mathrm{Fe}$. Mean concentration of $\mathrm{Mn}$ in the ambient rainwater ranged from $0.03 \mathrm{mgL}-1$ to $1.90 \mathrm{mgL}-1$ in the rusted galvanized iron roofing sheet. In a similar study, The main sources of $\mathrm{Zn}$. $\mathrm{Cu}$ and $\mathrm{Pb}$ in urban runoff water are roof corrosion ${ }^{[32]}$ and vehicular traffic leaching these elements during tire and brake wearing, gas emissions and corrosion of metallic pieces. Chang et al. ${ }^{[14]}$ found out that older roofs leach more metals, suggesting that the age of the roof can negatively affect the quality of harvested rainwater, while Wallinder et al. ${ }^{[30]}$ found that the inclination of the roof surface also affects the concentration of micro-pollutant with steeper inclinations resulting in lower concentrations. Furthermore, He et al. ${ }^{[33]}$, observed that precipitation intensity also influence the concentration of micro-pollutant in rooftop runoffs as light rainfall results in higher concentrations than a heavy rainfall. This is due to the longer contact time during light rainfall. In addition, the exposure direction also affects the concentration, with highest micro-pollutants concentration found from runoff of roofs facing the prevailing wind.

All the concentrations of $\mathrm{Cu}$ detected in the samples except for the ambient rainwater were above the WHO limit of $0.01^{[28]}$. Simmons et al. ${ }^{[26]}$ in a study of harvested rainwater quality from 125 residential roofs in New Zealand found that less than $2.4 \%$ of the samples exceeded drinking water standards for zinc and copper. Relative abundance of metals in harvested rainwater in terms of roof catchments is as follows: asbestos $>$ rusted galvanized iron sheet $>$ aluminium longspan sheet $>$ recent galvanized iron sheet $>$ ambient rainwater. In terms of abundance of individual metal, relative abundance is as follows: $\mathrm{Fe}>\mathrm{Zn}>\mathrm{Cu}>\mathrm{Mn}>\mathrm{Pb}>\mathrm{Cd}$ compared to $\mathrm{Cu}>\mathrm{Cr}>\mathrm{Ni}>\mathrm{Pb}>\mathrm{Cd}$ reported by Ruban et al. ${ }^{[4]}$. There is a strong positive correlation of 0.873 between $\mathrm{Zn}$ and all other metals at 0.05 significant levels. All the metal are significantly and positively correlated with each other (Table 6), an indication of the close association among the metals and the fact that as one occur, the others are likely to occur simultaneously. It is worth noting that large differences in runoff pollutant concentrations 
Micro-pollutants in urban residential roof runoff: Environmental and health implications.

from various roofs indicate that the pollutants were not only being transported to the surface via the atmosphere, but also originating from the material itself ${ }^{[8,13,18,34]}$.

Table 5. Correlations (PPMCC) among the heavy metals in the harvested rainwater

\begin{tabular}{lllllll}
\hline & Cd & Cu & Fe & Pb & Mn & Zn \\
\hline $\mathbf{C d}$ & 1.00 & & & & & \\
$\mathbf{C u}$ & 0.93 & 1.00 & & & & \\
$\mathbf{F e}$ & 0.98 & 0.95 & 1.00 & & & \\
$\mathbf{P b}$ & 0.99 & 0.97 & 0.98 & 1.00 & 1.00 & 1.00 \\
$\mathbf{M n}$ & 0.90 & 0.92 & 0.91 & 0.92 & 0.71 & 0.87 \\
$\mathbf{Z n}$ & 0.91 & 0.77 & 0.92 & 0.71 & \\
\hline
\end{tabular}

3.4. Polycyclic Aromatic hydrocarbons (PAHs)

Although the study area is an urban centre, low concentrations of total PAHs were observed in this study. The highest concentration of 0.18 total PAHs was found in the in rusted galvanized iron sheet compared to the 0.04 found in ambient rainwater (Table 7). The major contributors of organic compounds to roof runoff are atmospheric deposition, house heating and traffic emissions ${ }^{[8]}$. Apart from the leaching of heavy metals from the rooftops, organic compounds such as PAHs can also accumulate during dry and wet deposition ${ }^{[14]}$. In this study, PAHs concentrations were generally low and in many instances close to the quantification limits.

Table 6. Polycyclic Aromatic Hydrocarbon in water samples

\begin{tabular}{|l|l|}
\hline Roof type & Total PAHs \\
\hline Bulk open precipitation (Rainwater) & 0.04 \\
\hline Recent galvanized iron sheet & 0.07 \\
\hline Rusted galvanized iron sheet & 0.18 \\
\hline Aluminium longspan sheet & 0.06 \\
\hline Asbestos & 0.07 \\
\hline
\end{tabular}

However, other studies have detected a range of organic compounds in ambient rainwater samples, including polycyclic aromatic hydrocarbons (PAHs) and pesticides, with concentrations exceeding USEPA drinking water standards ${ }^{[36]}$. It is worth mentioning that PAHs represents the largest class of suspected carcinogens ${ }^{[34]}$ prevalent in urban atmospheric deposition. Only 6 out of the 15 PAHs investigated were detected in this study and these are: (FTH, PYR, BaA, BaP, IcdP, BghiP) which are of different origins such as incomplete combustion of diesel and gasoline, wear of asphalt or tyres ${ }^{[37-38]}$.

\subsection{Microbiological Contaminants composition}

Microbiological quality and health risk associated with roof harvested rainwater has been investigated widely, mainly with respect to public health where the roof water is used for drinking water supplied ${ }^{[12]}$. Total coliform (TC) and faecal coliform (FC) counts generally increase from the ambient rainwater to the different roof catchments. The entire sample collected during this study contains high amount of microbiological contaminants indicating the need for treatment before potable use ${ }^{[11]}$. The asbestos roofing contains the highest TC and Escherichia coli (E. coli), which are 14000 and $12000 \mathrm{cfu} / \mathrm{mL}$ respectively. Faecal coliform (FC) and heterotrophic plate count (HPC) were however higher in the rusted galvanized iron sheet (Figure 5). Mean microbial counts found in the rooftop runoff for the complete sample set were HPC, $6000 \mathrm{cfu} / \mathrm{mL}$; E. coli., 9000 $\mathrm{cfu} / \mathrm{mL}$; TC, $9750 \mathrm{cfu} / \mathrm{mL}$; and FC, $6050 \mathrm{cfu} / \mathrm{mL}$ (Figure 5). Percentage contributions of the pathogens to pollution of harvested rainwater under rusted galvanized iron sheets are the $21.4 \%$ TC, $16.1 \%$ FC, $44.6 \%$ HPC and $17.9 \%$ E. coli. HPC however was of the highest percentage in all the harvested rainwater including the ambient rainwater that is of $60 \%$ HPC (Figure 5). Mean microbial counts in this study are comparable with contaminant levels found previous studies of rainwater harvested from rooftops ${ }^{[25]}$. It is also consistent with those found in samples taken from roofed rainwater storage tanks ${ }^{[26,39]}$. 

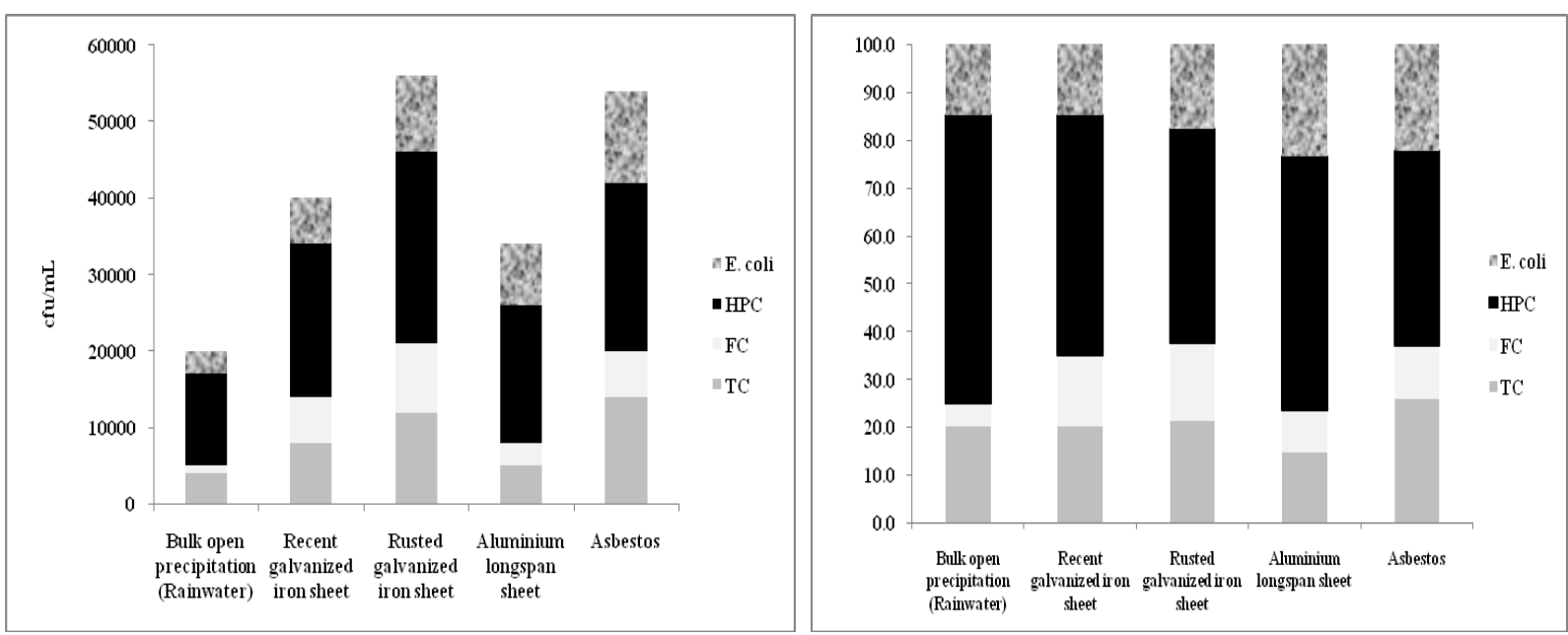

Figure 5. Microbial contributions to contamination in harvested rainwater on the left and their share (\%) on the right.

Faecally derived pathogens are of serious concerns in the safety of harvested rainwater. E. coli belongs to a diverse group of bacteria, which are mostly harmless, but some can cause sickness such as diarrhea, urinary tract infections, respiratory illness and pneumonia. Certain kinds of $E$. coli are indicating that the water is contaminated. The potential pollutants in rainwater harvesting systems are likely to arise from depositions by birds, small mammals, airborne microorganisms and chemical contaminants ${ }^{[12,26]}$. Normally, ambient rainwater is not supposed to contain microbial contaminants. In fact, Yaziz et al. ${ }^{[25]}$ found no TC or FC in ambient rain collected in the open from one meter from the ground. However, ambient rainwater collected in this study contained TC concentrations of $4000 \mathrm{cfu} / \mathrm{mL}$, FC concentrations of $1000 \mathrm{cfu} / \mathrm{mL}$ and HPC concentration of $12000 \mathrm{cfu} / \mathrm{mL}$, which were relatively high. This is due to contamination sources, including airborne deposition or birds that might have disturbed the samplers ${ }^{[1]}$. Faecal contamination of drinking water is a major contributor to diarrhoea and water borne disease that is responsible for the death of millions of children every year ${ }^{[40]}$. Harvested rainwater contains significant micro-pollutants, which poses health risk and this call for careful management of atmospheric pollution in urban areas.

\section{CONCLUSION}

Analysis of roof runoff show varying degrees of contaminant concentrations caused by leaching of roofing materials. The overall contribution of roofs to the contamination of roof runoff is significant for EC and TDS. $\mathrm{Fe}, \mathrm{Zn}$ and $\mathrm{Cu}$ are the most serious pollutants in the roof runoff. $\mathrm{Cu}$ in the runoffs from rusted galvanized iron sheet and asbestos is higher than the WHO guideline. While there is low concentrations of total PAHs, roof runoff contains high amount of microbiological contaminants, which are above the recommended limits for drinking water. The study revealed that roof runoff is a potential source of nonpoint pollution because roofs typically make up a significantly proportion micro-pollutants which are detrimental to health and hygiene. Using less of materials associated with identified pollutants would reduce pollution from runoff. Harvested rainwater needs treatment before potable use to reduce high rates of sickness and mortality from preventable water-related diseases.

[1] WHO (2010).WHO/UNICEF. Joint Monitoring Report Progress on Sanitation and Drinking Water, 2010. Available at: http://www.who.int/water_sanitation_health/monitoring/fast_fact/en/index.html (Accessed on July 12 2013).

[2] UNEP "Vital Water". 2002. Available at: http://www.unep.org/vitalwater/summary.htm (Accessed June 27, 2011).

[3] C. Zorn, and D. Wheatley, Rainwater Harvesting - An option to reduce demand on the Akaroa potable water supply". A report submitted in partial fulfilment of the requirements for the BE (Hons) Degree in Natural Resources Engineering, University of Canterbury, New Zealand. 2009.

[4] V. Ruban, K. Lamprea, and D. Deneele, Characterisation of atmospheric deposition and runoff water from a small suburban catchment. 2010. NOVATECH 2010

[5] M.C. Gromaire-Mertz, P. Robert-Sainte, A. Bressy, M. Saad, B. de Gouvello, and G. Chebbo, G. Zn and Pb emissions from roofing materials-Modelling and mass balance attempt at the scale of a small urban catchment. Wat. Sci. Tech., 63(11), 2011, 2590-2597.

[6] W. Zhang, S. Li, and F. Tang Characterization of Urban Runoff Pollution between Dissolved and Particulate Phases. The Scientific World Journal. Volume 2013, Article ID 964737, 6 pages. 2013. Available at: http://dx.doi.org/10.1155/2013/964737 (Accessed on July 12 2013).

[7] O.J. Achadu, F.E. Ako, and C.L. Dalla, Quality Assessment of Stored Harvested Rainwater in Wukari, North-Eastern Nigeria: Impact of Storage Media. IOSR Journal Of Environmental Science, Toxicology And Food Technology (IOSR-JESTFT) 7(5), 2013, 25-32 www.iosrjournals.org 
[8] S. Tsakovski, M, Tobiszewski, V. Simeonov, Z. Polkowska, and J. Namieśnik, J. "Chemical composition of water from roofing Gdansk, Poland". Environ. Pollut. Vol. 158, 2010, 84

[9] P.C. Van Metre, B.J. Mahler, and E.T. Furlong, Urban sprawl leaves it's PAH signature. Environ. Sci. Technol. 34, 2000, 40644070.

[10] I.F. Adeniyi, and I.O. Olabanji, The physico-chemical and bacteriological quality of rainwater collected over different roofing materials in Ile-Ife, South-western Nigeria. Chemistry and Ecology, 21(3) (2005):149-166.

[11] Mendez, C.B., Afshar B.R., Kinney, K., Barrett, M.E., and Kirisits, M. J. (2010). "Effect of Roof Material on Water Quality for Rainwater Harvesting Systems". Texas Water Development Board, Austin, Texas

[12] Evans, C.A., Coombes, P.J. and Dunstan. R.H. (2006). Wind, rain and bacteria: The effect of weather on the microbial composition of roof-harvested rainwater. Wat. Res. 40,37 - 44 .

[13] N.S. Miguntanna, P. Egodawatta, and A. Goonetilleke, Pollutant characteristics on roof surfaces for evaluation as a stormwater harvesting catchment". Desalination and Water Treatment, 19, 2010, 205-211.

[14] M. Chang, M.W. McBroom, and R.S. Beasley, Roofing as a source of non-point water pollution. J. Environ. Man., 73, $2004,307-$ 315 .

[15] USEPA. Drinking water contaminants. 2009. Available at: http://www.epa.gov/safewater/contaminants/index/html Accessed June 27,2011

[16] R.P. Schwarzenbach, B.I. Escher, K. Fenner, T.B. Hofstetter, C.A. Johnson, U. von Gunten, and B. Wehrli,. The challenge of micropollutants in aquatic systems. Science 313, 2006, 1072-1077.

[17] R. Triebskorn, K. Amler, L. Blaha, C. Gallert, S. Giebner, and H. Güde, et al. SchussenAktivplus: reduction of micropollutants and of potentially pathogenic bacteria for further water quality improvement of the river Schussen, a tributary of Lake Constance, Germany. Environmental Sciences Europe, 25, 2013, 2-9

[18] Sellami-Kaaniche, E., de Gouvello, B., Le Bris, A., Gromaire-Mertz, M.C., and Chebbo, G. Modelling the Zn emissions from roofing materials at Créteil city scale - Defining a methodology. Chapter 7. Proceedings, 12th World Wide Workshop for Young Environmental Scientists WWW-YES-2012 urban waters: resource or risks? Arcueil, France (21 - 25 May 2012).

[19] National Population Commission (NPC) Population Census of the Federal Republic of Nigeria: Analytical Report at the National Level. National Population Commission, Abuja. 2006

[20] P. Egodawatta, E. Thomas, and A. Goonetilleke, Understanding the physical processes of pollutant build-up and wash-off on roof surfaces. Sci. Total Environ, Vol. 407, 2009, 1834-1841.

[21] K. Lamprea and V. Ruban Micro pollutants in atmospheric deposition, roof runoff and storm water runoff of a suburban Catchment in Nantes, France. 11th International Conference on Urban Drainage, Edinburgh, Scotland, UK, 2008.

[22] APHA Standard Methods for the Examination of Water and Waste Water, Public Health Association, Washington, DC, USA. 2005.

[23] Hach. Procedures Manual for DR-2000 Spectrophotometer Nitrate NitraVer Test N' Tubes. Hach Co., P.O. Box 389, Loveland, CO. 2003.

[25] M. Yaziz, H. Gunting, N. Sapari, and A. Ghazali Variations in rainwater quality from roof catchments, Wat. Res. Vol. 23, No. 6, 1989, 761-765.

[26] G. Simmons, V. Hope, G. Lewis, J. Whitmore, and G. Wanzhen, Contamination of potable roof-collected rainwater in Auckland, New Zealand. Water Res. 35, 2001, 1518-1524

[27] P.R. Thomas, and G.R. Greene. 1993. "Rain Water Quality From Different Roof Catchments." Water science technology. 28(35) pp. 291-293

[28] WHO (2011). "Guidelines for Drinking-water Quality". Fourth Edition. Available at: http://www.who.int (Accessed on July 12 2013).

[29] D.J. Lye, Health risks associated with consumption of untreated water from household roof catchment systems. Journal of the American Water Resources Association 38(5), 2002, 1301-1306.

[30] S. Azimi, V. Rocher, M. Muller, R. Moilleron, and S. Thevenot, Sources, distribution and variability of hydrocarbons and metals in atmospheric deposition in an urban area (Paris, France). Sci. Total Environ, 337, 2005, 223-239

[31] K. Athanasiadis, H. Horn, . and B. Helmreich, A field study on the first flush effect of copper roof runoff. Corrosion Science, 52(1), 2010, 21-29.

[32] M.C. Gromaire-Mertz, S. Garnaud, M. Saad. and G. Chebbo, G. Contribution of different sources to the pollution of wet weather flow in combined sewers. Wat. Res., 35(2), 2001, 521-533.

[33] W.I. He, I. O. Wallinder, and C. Leygraf, A comparison between corrosion rates and runoff rates from new and aged copper and zinc as roofing material. Water, Air, Soil Poll. Focus 1. 2001, 67-82.

[34] A. Björseth, and T. Ramdahl (Eds.), Handbook of Polycyclic Aromatic Hydrocarbons, Vol. 2. (Marcel Dekker, New York, p. 432. 1985).

[35] I.O. Wallinder, P. Verbiest, and C. Leygraf, Effects of exposure direction and inclination on the runoff rates of zinc and copper roofs, Corrosion Science, 42, 2000, 1471-1487.

[36] C. Basheer, R. Balasubramanian, and H.K. Lee, Determination of organic micropollutants in rainwater using hollow fiber membrane/liquid-phase microextraction combined with gas chromatography-mass spectrometry. Journal of Chromatography A 1016(1),2003, 11-20.

[37] J. Gasperi. Introduction et transfert des hydrocarbures à différentes échelles spatiales dans le réseau d'assainissement parisien. Sciences et techniques de l'environnement Ph.D. Ecole National des Ponts et Chaussées, Paris. 2006.

[38] B.J. Mahler, and P.C. Van Metre, A simplified approach for monitoring hydrophobic organic contaminants associated with suspended sediment—methodology and applications. Arch. Environ. Contamin. Toxicol. 44(3), 2003,288-297.

[39] H.J. Albrechtsen Microbial investigations of rainwater and graywater collected for toilet flushing. Wat. Sci. Tech. 46, 2002, 311316 .

[40] UNICEF. Water, Sanitation and Hygiene. 2012. Available at: http://www.unicef.org/wash/index_43106.html (Accessed on July 12 2013). 